\title{
日本呼吸器外科学会総会 歴代会長一覧
}

\begin{tabular}{|c|c|c|c|c|}
\hline 回 数 & 会 & 長 & 開催地・会場 & 開 催 日 \\
\hline 第 1 回 & 寺松 & 孝 & 東京都・京王プラザホテル & 1984. 4.8 \\
\hline 第 2 回 & 正岡 & 昭 & 名古屋市・愛知県医師会館 & 1985. 4.9 \\
\hline 第 3 回 & 大田 & 満夫 & 福岡市・都久志会館 & 1986. 5. $23 \sim 24$ \\
\hline 第 4 回 & 仲田 & 祐 & 仙台市・仙台市民会館 & 1987. 5. 21 22 \\
\hline 第 5 回 & 末外 & 恵一 & 東京都・国立教育会館 & 1988. 6. 10 11 \\
\hline 第 6 回 & 岡田 & 慶夫 & 大津市・大津プリンスホテル & 1989. 5. 25 26 \\
\hline 第 7 回 & 石原 & 恒夫 & 東京都・ホテルオークラ & 1990. 5. 8 9 \\
\hline 第 8 回 & 富田 & 正雄 & 長崎市・長崎市公会堂、ほか & 1991. 5. 23 24 \\
\hline 第 9 回 & 尾形 & 利郎 & 大宮市・大宮ソニックシティ、ほか & 1992. 5. 20 21 \\
\hline 第 10 回 & 山口 & 豊 & 千葉市・ホテルニューツカモト、ほか & 1993. $6.3 \sim 4$ \\
\hline 第 11 回 & 人見 & 滋樹 & 京都市・京都パークホテル & 1994. 5. 13 14 \\
\hline 第 12 回 & 前田 & 昌純 & 高松市・サン・メッセ香川 & 1995. 5. 10 11 \\
\hline 第 13 回 & 藤村 & 重文 & 仙台市・仙台サンプラザ & 1996. 5. $9 \sim 10$ \\
\hline 第 14 回 & 渡辺 & 洋宇 & 金沢市・金沢市観光会館、ほか & 1997. 5. 8 9 \\
\hline 第 15 回 & 成毛 & 韶夫 & 東京都・東京国際フォーラム & 1998. 4. $28 \sim 29$ \\
\hline 第 16 回 & 新田 & 澄郎 & 東京都・京王プラザホテル & 1999. 5. $13 \sim 14$ \\
\hline 第 17 回 & 門田 & 康正 & 徳島市・徳島県郷土文化会館 & 2000. 5. 25 26 \\
\hline 第 18 回 & 加藤 & 治文 & 東京都・京王プラザホテル & 2001. 5. 10 11 \\
\hline 第 19 回 & 綾部 & 公懿 & 長崎市・長崎ブリックホール、ほか & 2002. 5. $23 \sim 24$ \\
\hline 第 20 回 & 小林 & 紘一 & 東京都・東京ドームホテル & 2003. 5. 8 10 \\
\hline 第 21 回 & 吉村 & 博邦 & 横浜市・パシフィコ横浜 & 2004. 5. 27 $\sim 29$ \\
\hline 第 22 回 & 和田 & 洋巳 & 京都市・国立京都国際会館、ほか & 2005. 6. $2 \sim 4$ \\
\hline 第 23 回 & 長田 & 博昭 & 東京都・東京プリンスホテル & 2006. 5. 25 27 \\
\hline 第 24 回 & 井上 & 宏司 & 横浜市・パシフィコ横浜、ほか & 2007. 5. 17 19 \\
\hline 第 25 回 & 蘇原 & 泰則 & 宇都宮市・栃木県総合文化センター & 2008. 5. 29 30 \\
\hline 第 26 回 & 安元 & 公正 & 北九州市・北九州国際会議場、ほか & 2009. 5. 14 16 \\
\hline 第 27 回 & 近藤 & 丘 & 仙台市・仙台国際センター & 2010. 5. 13 15 \\
\hline 第 28 回 & 川原 & 克信 & 別府市・別府国際コンベンションセンター & 2011. 5. 12 13 \\
\hline 第 29 回 & 小川 & 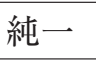 & 秋田市・秋田県民会館、ほか & 2012. 5. 17 18 \\
\hline 第 30 回 & 藤井 & 義敬 & 名古屋市・名古屋国際会議場 & 2013. 5. 9 10 \\
\hline 第31 回 & 金子 & 公一 & 東京都・ホテル日航東京 & 2014. 5. 29 30 \\
\hline 第 32 回 & 横見瀬 & 裕保 & 高松市・サンポートホール高松、ほか & 2015. 5. 14 15 \\
\hline 第33 回 & 伊達 & 洋至 & 京都市・国立京都国際会館 & 2016. 5. 12 13 \\
\hline 第 34 回 & 岩㠃 & 昭憲 & 福岡市・福岡国際会議場 & 2017. 5. 18 19 \\
\hline 第 35 回 & 吉野 & 一郎 & 千葉市・幕張メッセ & 2018. 5. 17 18 \\
\hline
\end{tabular}

第 1 回〜第 3 回までは呼吸器外科研究会と称したが、第 4 回（昭和 62 年）より正式名称は日本呼吸器外科 学会総会となる。 